8 Schlichter, J, et al, Medicine, 1954, 33, 43.

9 Duke, D, American Heart fournal, 1971, 82, 486.

10 Levine, S A, and Lown, B, fournal of the American Medical Association, 1952, 148, 1365.

11 Groden, B M, et al, Scottish Medical fournal, 1967, 12, 435.

12 Adgey, A A J, British Heart fournal, 1969, 31, 750.

13 Harpur, J E, et al, Lancet, 1971, 2, 1331.

14 Royston, G R, British Heart fournal, 1972, 34, 526.

16 Tucker, H H, et al, British Medical fournal, 1973, 1, 10.

16 Medical Division, Royal Infirmary, Glasgow, Lancet, 1973, 2, 346.

17 Hayes, M J, et al, British Medical fournal, 1974, 3, 10.

18 Abraham, A S, et al, New England fournal of Medicine, 1975, 292, 719.

19 Thornley, P E, and Turner, R W D, British Heart Fournal, 1977, 39, 471.

${ }^{20}$ Mitchell, J R A, and Parish, D J, British Medical fournal, 1960, 2, 1626.

${ }^{21}$ Mather, H G, et al, British Medical fournal, 1976, 1, 925.

${ }^{22}$ Medalie, J H, and Goldbourt, U, Annals of Internal Medicine, 1976, 84, 526.

${ }^{23}$ Lancet, 1976, 2, 449.

24 Joint Working Party, Royal College of Physicians of London and British Cardiac Society, Fournal of the Royal College of Physicians, 1976, 9, 281. 25 Groden, B M, et al, British Heart fournal, 1971, 33, 756.

${ }^{26}$ Carson, P, et al, British Medical fournal, 1973, 4, 213.

27 Kushnir, B, et al, Scandinavian fournal of Rehabilitation Medicine, 1975, 7, 158.

\section{Day services for mentally handicapped adults}

Many of the mildly handicapped committed to hospital in the past as feeble-minded were in fact capable of remunerative work and could have been integrated into the general community. ${ }^{1}$ Indeed, classification was imprecise, and many of this group were within the normal range of intelligence. ${ }^{2}$ In addition, the more severely handicapped (formerly termed imbeciles) are nowadays known to be capable of useful work in a sheltered setting, given suitable training and facilities. ${ }^{3}$ For much of this century a major shortcoming on the part of those providing for the mentally handicapped has been the underestimation of their potential for social adaptation. ${ }^{4}$

As attitudes and expectations have changed demands have grown for community care and "normalisation." As Penrose ${ }^{5}$ put it, "Civilised communities must learn to tolerate, to absorb, and to employ the scholastically retarded and to pay more attention to their welfare." Community care is a fine slogan, but all too often the sole alternative to admission of the more severely handicapped to an institution has been a perpetual domestic burden for parents, with all the selfsacrifice that this entails. There were few occupation centres before the second world war and almost none when it ended, but more recently there has been a dramatic increase in the number of places available. (Since the 1970 Education Act came into effect in 1971 severely mentally handicapped children have been included within the educational system as of right, so that training centres, as the former occupation centres are now called, relate strictly to adults.)

In a preface to what is modestly described as a pamphlet ${ }^{6}$ by the National Development Group for the Mentally Handicapped-in reality an excellent miniature textbook and guidethe Secretary of State for Social Services gives a figure of 24500 for 1969 with a target of 73000 over 20 years and a 1976 achievement of 34000 places in adult training centres. Gratifying though this rise may be, it does not help those many families with a handicapped member at home all day with no suitable occupation or training. The problem is most severe with the most severely handicapped: only $13 \%$ of training centres have a special care unit, ${ }^{7}$ while others are inclined to refuse individuals with multiple handicap or profound retardation. These are the very cases whose families have the greatest need for daily relief from their care.

The National Development Group suggests that in future adult training centres be known as social education centres, a welcome shift of emphasis towards continued education and training as opposed to mere occupation. Much, however, depends on resources. The DHSS has repeatedly stated that current economies must not affect the plans for the mentally handicapped, so long neglected. But if there are overall cuts in budgets of local authorities and health authorities it is difficult to believe the programme will not suffer. Again, ideally the mildly handicapped should find work in the community, but with rising unemployment they compete instead with the severely handicapped for places in training centres. The National Development Group rightly says that labels such as "over-protecting" or "rejecting" should be avoided in describing families of the handicapped, but unless urgently needed places in centres are provided both terms may well apply. The designation "occupation centre" may be outmoded, but nevertheless occupation is of cardinal importance. The pamphlet devotes a brief chapter to preparation for work, but in reality it is only the mildly handicapped who can hope for open employment, and this after much effort. A rational economy would provide adequate employment for the mentally handicapped of all grades in industry and ordinary work-places as well as in specialised centres.

${ }^{1}$ O'Connor, N, and Tizard, J, The Social Problem of Mental Deficiency. London, Pergamon Press, 1956.

${ }^{2}$ Kirman, B H, and Bicknell, J, Mental Handicap. Edinburgh, Churchill Livingstone, 1975.

${ }^{3}$ Mental Deficiency-the Changing Outlook, ed A M Clarke and A D B Clarke, 3rd edn. London, Methuen, 1974.

4 Clarke, A D B, and Hermelin, B F, Lancet, 1955, 2, 337.

5 Penrose, L S, The Biology of Mental Defect, 4th edn. London, Sidgwick and Jackson, 1972.

${ }^{6}$ National Development Group for the Mentally Handicapped, Day Services for Mentally Handicapped Adults. London, HMSO, 1977.

Whelan, E, and Speake, B, Adult Training Centres in England and Wales: Report of the First National Survey. Manchester, University of Manchester, Hester Adrian Research Centre, 1977.

\section{Control of salmonellosis in poultry and cattle}

Salmonellosis in animals causes serious economic loss to farmers and food producers, and it is also the source of many human infections. Thus the decision to make vets responsible for implementing the Zoonoses Order of 1975 seems sensible. Nevertheless, the medical and veterinary approaches to the control of salmonellosis differ considerably. ${ }^{1}$

Of the 23609 cases of salmonellosis occurring in animals during $1968-74,86 \%$ occurred in cattle, $7 \%$ in poultry, $3 \%$ in sheep, and $2 \%$ in pigs; furthermore, the incidence in poultry seems to be decreasing. Yet most human salmonellosis in the United Kingdom is attributed to poultry and pork. ${ }^{2-4}$ These figures suggest a conflict of interest between the veterinarians, who will be concerned mainly with cattle, and the medical profession, whose efforts at control will be aimed more at poultry and pigs.

Salmonellas cause symptoms in cattle more often than in pigs or poultry, so cattle infections are clearly more likely to be investigated. But both fowls and pigs can excrete salmonella serotypes that have been introduced in animal feed without 